\title{
AKTSAR
}

ISSN 2622-5255 (online)

\section{Lingkungan Pengendalian Pengelolaan Dana Kapitasi di Puskesmas Tanjung Selor Kalimantan Utara}

\author{
Elisa Husnul Anisa \\ Universitas Airlangga \\ nieza_anto@yahoo.co.id \\ Heru Tjaraka \\ Universitas Airlangga \\ heru_tjaraka@yahoo.co.id
}

ABSTRACT

The number of fraudulent acts on the management of capitation funds in various regions in Indonesia as a background in this study. The system was implemented by the Tanjung Selor health center and the Bulungan District Health Office in North Kalimantan in managing capitation funds without any fraud. This study using the case study method to examine the events faced in the management of capitation funds by research subjects. The findings indicate that there is not yet official regulation regarding the control system that is used as a guideline in the management of capitation funds. Control activities have been carried out, but only based on the obligations that must be carried out so that no fraud will occur.

Keywords: Control activities; Fund capitation; Management; Health center 


\begin{abstract}
ABSTRAK
Banyaknya tindak kecurangan terhadap pengelolaan dana kapitasi di berbagai daerah di Indonesia, menjadikannya sebagai latar belakang dalam penelitian ini. Sistem apa yang diterapkan oleh puskesmas Tanjung Selor dan Dinas Kesehatan Kabupaten Bulungan di Kalimantan Utara dalam mengelola dana kapitasi tanpa terdapat kecurangan di dalamnya. Penelitian ini menggunakan metode studi kasus guna menelaah kejadian yang dihadapi dalam pengelolaan dana kapitasi oleh subyek penelitian. Hasil temuan menunjukkan bahwa belum terdapatnya suatu peraturan resmi mengenai sistem pengendalian yang dipergunakan sebagai pedoman dalam pengelolaan dana kapitasi. Kegiatan pengendalian telah dilakukan, namun hanya berdasarkan atas kewajiban yang harus dilakukan agar tidak terjadi tindak kecurangan.
\end{abstract}

Kata kunci: Kegiatan pengendalian; Dana kapitasi; Pengelolaan; Puskesmas.

\title{
PENDAHULUAN
}

Pelaksanaan program JKN oleh BPJS Kesehatan dimulai per 1 Januari 2014, diikuti dengan berbagai peraturan perundangan sebagai payung hukum. Peraturan Presiden (Perpres) Nomor 32 Tahun 2014 mengenai Pengelolaan dan Pemanfaatan Dana Kapitasi Jaminan Kesehatan Nasional pada Fasilitas Kesehatan Tingkat Pertama Milik Pemerintah Daerah merupakan landasan hukum awal yang dibuat dan diundangkan pada 21 April 2014. Perpres tersebut dimaksudkan sebagai landasan hukum bagi puskesmas maupun fasilitas kesehatan lainnya dalam hal pengelolaan dana kapitasi.

Kapitasi merupakan sebuah metode pembayaran yang diberikan kepada fasilitas kesehatan dengan besaran yang sama untuk setiap pasien tanpa memperhatikan jumlah serta tindakan medis yang telah diberikan kepada pasien. Dana kapitasi adalah dana kompensasi yang diberikan langsung kepada puskesmas atas pelayanan terhadap pasien peserta jaminan kesehatan (Permenkes, 2016). Dana kapitasi bersumber dari hasil pengumpulan dana iuran peserta jaminan kesehatan. Pemberian dana kapitasi ini dilakukan dengan tidak melihat jenis tindakan medis yang telah dilakukan oleh fasilitas kesehatan terhadap pasien dan diberikan setiap bulan langsung melalui rekening puskesmas sesuai dengan jumlah keanggotaan jaminan kesehatan di wilayah kerjanya. Dengan diserahkannya dana kapitasi langsung kepada puskesmas, diharapkan bisa secara maksimal memberikan pelayanan kesehatan bagi seluruh masyarakat, terlebih masyarakat yang kurang mampu diwilayahnya. Atas pengelolaan dana tersebut, telah pula diterbitkan regulasi pengelolaannya untuk mempermudah puskesmas dalam mengelola, mengingat dana tersebut sangat besar, apabila tidak diterbitkan regulasi atas pengelolaannya, dikhawatirkan akan terjadi kecurangan dalam penggunaannya. 
Peraturan Pemerintah Nomor 60 Tahun 2008 tentang Sistem Pengendalian Intern Pemerintah menjelaskan bahwa tata kelola keuangan daerah yang lebih akurat dan terbuka dapat terwujud apabila seluruh komponen kepala instansi di daerah melaksanakan aktivitas pengendalian terhadap keseluruhan proses aktivitas yang berawal dari perencanaan, pelaksanaan, pengawasan, sampai proses terakhir yaitu pertanggungjawaban secara teratur, di bawah kontrol, efektif dan efisien. Guna mencapai tujuan tersebut diperlukan suatu metode yang dapat meyakinkan secara memuaskan bahwa pelaksanaan aktivitas suatu lembaga pemerintah akan mendapatkan tujuannya secara efektif dan efisien, melaporkan pengelolaan keuangan daerah secara andal, mengamankan aset daerah, mendorong ketaatan terhadap peraturan perundang-undangan.

Pemerintah daerah, dalam mewujudkan misi lembaganya, memerlukan suatu sistem pengendalian intern yang berguna untuk mengawasi praktek kegiatan sehingga pencapaian misi lembaga lebih terjamin sebagaimana yang telah ditetapkan. Tujuan pengendalian internal pada Pemerintah Daerah akan tercapai dengan dilaksanakannya unsur-unsur dan sub unsur sistem pengendalian internal di lingkungan Pemerintah Daerah yaitu Lingkungan Pengendalian, Penilaian Resiko, Kegiatan Pengendalian, Informasi dan Komunikasi, dan Pemantauan Sistem Pengendalian Intern.

Semakin berkembangnya tingkat penyalahgunaan atas dana pelayanan kesehatan di dalam ranah pemerintah daerah pada masa sekarang ini sudah sampai pada kondisi yang mengkhawatirkan. Bilamana mengikut pada UU No. 30 Tahun 2002 mengenai KPK, penyalahgunaan dana kapitasi dapat dikategorikan sebagai bencana kesehatan. Awal peluncuran program JKN adalah 1 Januari 2014, namun penjarahan dana kapitasi BPJS Kesehatan oleh berbagai oknum di jajaran Pemerintah Daerah juga tengah berlangsung. Penjarahan tersebut semakin meluas dan terencana sehingga mengakibatkan terampasnya hak-hak masyarakat akan pelayanan kesehatan. Penjarahan dana kapitasi ini telah menjadi suatu tindak kriminal besar dengan ancaman hukuman yang lebih berat dan metode penegakan hukum yang luar biasa.

Pengelolaan dana kapitasi oleh pemerintah daerah dinilai menjadi ladang korupsi karena tidak adanya alat pengawasan dan pengendalian. Peraturan Nomor 32/2014 dinilai dapat dimanfaatkan kepala daerah untuk memainkan dana kapitasi. Sebagaimana diketahui, alokasi untuk pembayaran jasa kesehatan hanya ditentukan $60 \%$ sebagai alokasi syarat minimal. Sementara itu, 40\%-nya digunakan untuk biaya operasional FKTP. Indonesia memiliki hampir 18.000 fasilitas kesehatan dengan rerata pendapatan Rp 400 juta setiap tahun (Budiarto, 2015).

Sebuah ironi mengingat Inpres No. 5/2004 mengenai percepatan pemberantasan korupsi di mana Presiden memberi perintah kepada Gubernur dan Bupati/Walikota untuk memberikan pelayanan publik lebih baik serta menghapus segala pungli dalam pelaksanaannya dan bersinergi dengan DPRD meminimalisir dan mencegah kesempatan adanya kebocoran atau manipulasi keuangan negara yang berasal baik dari APBN maupun APBD. Dana kapitasi BPJS Kesehatan juga sebagian bersumber dari APBN, dan sebagian besar bersumber dari dana publik yang telah menjadi peserta JKN. Belum lagi pemda juga diwajibkan mengalokasikan anggaran untuk kesehatan minimal 10\% dari APBD sesuai UU 36 Tahun 2009. Dua sumber dana 
pada FKTP itu pun berpotensi menciptakan tumpang tindih penggunaan anggaran dana kesehatan, baik yang bersumber dari APBD maupun dana kapitasi yang diberikan oleh BPJS Kesehatan.

Bidang kesehatan pada saat ini juga telah menjadi sorotan oleh pihak KPK, mengingat adanya dana kapitasi yang memiliki celah terbuka akan terjadinya kecurangan di dalam pengelolaannya. Hal ini telah mulai diamati oleh KPK sejak tahun 2015. Saat itu, KPK berhasil mendapatkan berbagai kelemahan, diantaranya mengenai tingkat efektivitas dana kapitasi untuk memberikan pelayanan terbaik masih lemah, sementara itu dana yang dikelola puskesmas/fasilitas kesehatan sudah sangat besar, berkisar Rp 8 triliun per tahun. KPK menyebutkan, penyebab rendahnya efektivitas dana kapitasi bermula dengan belum adanya perangkat pengawasan dan pengendalian untuk dana kapitasi. "Saat ini terdapat hampir 18.000 FKTP di seluruh Indonesia dengan rata-rata pengelolaan dana kapitasi sekitar Rp 400 juta per tahun tiap FKTP," kata KPK. Selain itu memang dana kapitasi rentan disalahgunakan. Salah satunya berkenaan dengan pengalokasian untuk jasa pelayanan dan operasional yang berakibat munculnya moral hazard, dimana apabila terjadi kecurangan bukan pelaku yang menanggung akibatnya namun orang lain menanggung akibat tersebut. Perpres mengatur minimal $60 \%$ untuk jasa pelayanan. Dengan demikian, banyak daerah kemudian yang mengatur $80 \%$ untuk jasa pelayanan. Dan, karena pembagiannya masih tunai, saat pembagian, dana tersebut rentan dipotong atau dikutip (Kompas, 2018).

Kabupaten Bulungan memiliki 12 puskesmas yang bertindak selaku fasilitas kesehatan bagi peserta BPJS, yang berjumlah 54.567 jiwa. Total Dana kapitasi total yang disalurkan kepada puskesmas wilayah Kabupaten Bulungan sebesar Rp.3.468.436.300,- pada tahun 2016. Penelitian mengenai potensi kecurangan dalam pengelolaan dana kapitasi di pusat kesehatan masyarakat dipicu oleh program yang baru dilaksanakan dan peraturan yang tidak secara jelas mengenai penggunaan dana kapitasi BPJS oleh puskesmas beserta sumber daya manusia yang bertindak sebagai petugas pengelola kapitasi (Setiaji, 2015).

Berbagai permasalahan yang timbul dari pengelolaan dana kapitasi sebagaimana disampaikan menjadikan latar belakang bagi penulis untuk melakukan penelitian mengenai pengendalian internal dalam hal pengelolaan dana kapitasi di Puskesmas Tanjung Selor sebagai puskesmas penerima dana kapitasi terbesar dibandingkan dengan 12 puskesmas lainnya dimana keadaan tersebut rentan terhadap timbulnya kecurangan. Dengan adanya penelitian ini kita ingin mengetahui bagaimana sistem pengendalian yang digunakan pada saat ini dalam pengelolaan dana kapitasi sehingga bisa dilakukan perbaikan sesuai dengan peraturan yang berlaku apabila ditemukan adanya ketidaksesuaian.

Penelitian ini dilakukan pada Puskesmas Tanjung Selor dan Dinas Kesehatan Kabupaten Bulungan Kalimantan Utara yang merupakan gugus tugas yang memiliki hak otonomi di bidang kesehatan serta mempunyai kewajiban mengelola dana kapitasi yang pengelolaan harus disesuaikan dengan peraturan yang berlaku. Namun dalam prakteknya masih terdapat penyerapan anggaran yang tidak sesuai bahkan melebihi dari yang telah direncanakan. 


\section{TINJAUAN LITERATUR}

\section{Teori Regulasi}

Teori regulasi lahir diakhir tahun 1970-an, dimana situasi ekonomi sedang dilanda resesi, setelah mengalami masa kejayaan sekitar 20-30 tahun. Pada masa tersebut, perekonomian Eropa dan Amerika tengah memasuki masa politik sulit sejak krisis hebat di Amerika tahun 1930-an. Pengertian lain terkait teori regulasi adalah peraturan khusus yang dikeluarkan oleh pemerintah dalam mendukung terjalinnya hubungan yang serasi, seimbang, sesuai dengan lingkungan, nilai, norma, budaya masyarakat setempat, untuk mewujudkan pembangunan ekonomi yang berkelanjutan guna meningkatkan kualitas kehidupan dan lingkungannya.

Regulasi merupakan hasil dari tindakan penekanan kelompok yang menghasilkan hukum dan kebijakan untuk mendukung kalangan bisnis serta melindungi konsumen, pekerja, dan lingkungan, sedangkan menurut Badan Standardisasi Nasional, regulasi di Indonesia diartikan sebagai sumber hukum formil berupa peraturan perundang-undangan yang memiliki beberapa unsur, yaitu merupakan suatu keputusan yang tertulis, dibentuk oleh lembaga negara atau pejabat yang berwenang, dan mengikat umum.

Regulasi umumnya diasumsikan untuk dirancang dan dioperasikan demi kepentingan industri yang ada. Menurut Scott (2013) terdapat dua teori regulasi yaitu teori kepentingan publik (public interest theory) dan teori kepentingan kelompok (interest group theory). Teori kepentingan publik (public interest theory) menjelaskan bahwa regulasi harus dapat memaksimalkan kesejahteraan sosial. Teori ini diperlukan untuk menanggapi permintaan publik terhadap perbaikan praktik pasar yang tidak efisien dan tidak adil. Interest group theory menjelaskan bahwa regulasi adalah hasil lobi dari beberapa individu atau kelompok yang mempertahankan dan menyampaikan kepentingan mereka kepada pemerintah. Teori kepentingan kelompok (Interest group theory) ini berpandangan bahwa regulasi disediakan sebagai tanggapan atas permintaan kelompok tertentu untuk memaksimumkan pendapatan mereka.

Regulasi pada sektor publik perlu diciptakan sebagai bentuk pengawasan penyelenggaraan pemerintahan. Dalam manajemen pemerintahan modern, salah satu bentuk pengawasan adalah sistem pengendalian intern, yang merupakan suatu hal yang mutlak harus dibangun dan dilaksanakan pada setiap unit organisasi pemerintahan, yang tidak terbatas pada tingkat departemen dan lembaga negara saja, melainkan pemerintahan secara keseluruhan. Sistem pengendalian intern pemerintahan yang baik akan memberikan jaminan terhadap kualitas dan kinerja pemerintahan secara keseluruhan, sehingga penyelenggaraan pemerintahan dapat memenuhi prinsip-prinsip good governace dan terhindar dari tuntutan hukum dan administrasi (BPKP, 2008).

Kegiatan pengendalian merupakan salah satu dari lima unsur dalam SPIP dan hal ini adalah sebagai salah satu wujud dari regulasi. Sesuai pasal 13 ayat (1) PP 60 Tahun 2008 tentang SPIP, disebutkan bahwa pimpinan instansi wajib melakukan penilaian risiko. Peraturan Pemerintah Nomor 60 Tahun 2008 juga mewajibkan menteri/pimpinan lembaga, gubernur, dan bupati/walikota untuk melakukan pengendalian atas kegiatan penyelenggaraan pemerintahan melalui SPIP yang bertujuan untuk memberikan keyakinan yang memadai bagi tercapainya efektivitas 
dan efisiensi pencapaian tujuan penyelenggaraan pemerintahan negara, keandalan laporan keuangan, pengamanan aset negara, dan ketaatan terhadap peraturan perundang-undangan yang berlaku, sehingga pengelolaan keuangan negara akan efektif, efisien, transparan, dan akuntabel dapat tercapai.

\section{METODE}

Dalam studi ini, penulis menggunakan studi kualitatif. Studi kualitatif digunakan karena penulis ingin memperoleh informasi secara lebih mendalam, memahami pendapat dari narasumber, dan melakukan analisa mengenai pendapat dari narasumber tersebut melalui wawancara serta data sekunder yang berasal dari pengumpulan dokumentasi yang berkaitan dengan dana kapitasi yang diperoleh baik dari puskesmas Tanjung Selor maupun dari Dinas Kesehatan (Basuki, 2016).

Penelitian dilakukan di Puskesmas Tanjung Selor dengan pertimbangan bahwa puskesmas Tanjung Selor merupakan puskesmas penerima dana kapitasi terbesar di antara 12 puskesmas yang ada di Kabupaten Bulungan. Sebagai penerima dana kapitasi terbesar, tidak tertutup kemungkinan terjadinya tindak kecurangan apabila tidak terdapat suatu sistem yang bisa mengendalikan atas pengelolaan tersebut. Penelitian ini dilakukan

\section{HASIL DAN PEMBAHASAN}

Penulis melakukan wawancara dengan narasumber guna mengetahui kondisi lingkungan pengendalian dalam pengelolaan dana kapitasi pada Dinas Kesehatan dan Puskesmas Tanjung Selor Kabupaten Bulungan. Dalam mengelola dana kapitasi, baik Dinas Kesehatan maupun Puskesmas Tanjung Selor belum memiliki Standar Operasional Prosedur (SOP) serta sistem pengendalian secara resmi dan tertulis. Pengendalian hanya dilakukan berdasarkan petunjuk teknis dari kementrian kesehatan dan peraturan bupati tentang dana kapitasi. Hal ini sebagaimana disampaikan oleh bendahara kapitasi sebagai berikut :

"kami belum ada buat SOPnya mbak,harusnya memang ada,kemarin pada waktu akreditasi kami juga ditanya itu dan disuruh buat...dari perbup itu kami disuruh buat lagi kayak lebih internnya gitu...harusnya kita memang buat tapi kami bendahara yang disuruh buat,kita kan bingung juga.harusnya ada tim yang buat..."

Dalam menyikapi setiap ada pembaruan informasi dan peraturan tentang pengelolaan kapitasi, antara Dinas Kesehatan dengan Puskemas Tanjung Selor tidak terdapat perbedaan dalam pengaplikasian serta belum pernah ada salah penafsiran terhadap peraturan baru tersebut. Hal ini sebagaimana dinyatakan oleh bendahara kapitasi, dan senada dengan Kepala Sub Bagian Perencanaan dan Keuangan sebagai berikut :

"selama ini belum pernah terjadi kesalahan dalam menjalankan peraturan yang ada mbak..ya kita laksanakan seperti yang sudah ditetapkan..." 
Dengan demikian Dinas Kesehatan dan Puskesmas Tanjung Selor telah menunjukkan komitmen terhadap integritas dan etika. Hal ini ditunjukkan dengan adanya komitmen pimpinan terhadap kode etik dan etika serta peraturan tentang pengelolaan dana kapitasi, walaupun dalam pelaksanaanya masih mengalami kesulitan serta belum dibentuknya SOP dalam melaksanakan peraturan tersebut.

Kepala Dinas Kesehatan memegang tanggung jawab atas terciptanya lingkungan pengendalian terhadap pengelolaan dana kapitasi yang optimal. Hal ini sebagaimana yang disampaikan oleh Kepala Sub Bagian Perencanaan dan Keuangan sebagai berikut :

\begin{abstract}
"sebelum kita melapor bapak selalu bertanya duluan, bagaimana pelaksanaan kapitasi,progressnya sampai dimana bla bla, puskesmas mana yang bermasalah,cepat laporkan ke saya,masalahnya apa...beliau selalu respons atas pelaksanaan kapitasi di puskesmas..."
\end{abstract}

Kepala Dinas Kesehatan maupun pimpinan puskesmas Tanjung Selor juga mendukung penerapan Sistem Pengendalian Intern Pemerintah (SPIP), hal ini ditunjukkan dengan adanya respon yang sangat cepat terhadap perkembangan pengelolaan dana kapitasi. Respon yang cepat dan tanggapan yang positif dari Kepala Dinas Kesehatan beserta pimpinan Puskesmas Tanjung Selor terhadap pengelolaan dana kapitasi ditunjukkan dengan adanya lokakarya mini yang diselenggarakan setiap bulan antara pengurus dana kapitasi dengan petugas pelaporan beserta pimpinan baik yang ada di dinas kesehatan maupun di puskesmas. Selain itu juga mengikutsertakan pegawai dalam sosialisasi mengenai penatausahaan dana kapitasi yang diselenggarakan oleh pihak Badan Pengelola Keuangan dan Aset Daerah.

Pimpinan puskesmas juga telah mempertimbangkan resiko dalam mengambil keputusan. Hal ini harus dilakukan mengingat dana kapitasi berasal dari masyarakat yang penggunaannya harus tepat sehingga tidak terjadi kecurangan dalam pengelolaannya. Hal ini ditujukkan oleh pernyataan bendahara, senada dengan pimpinan puskesmas maupun kepala sub bag perencanaan dan keuangan, bahwa :

"ketika kita menyampaikan laporan setiap bulan, bos selalu melakukan crosscek lagi dengan data serta bukti yang ada,jadi tidak asal laporan diterima terus tanda tangan tapi tetap dilakukan pengecekan karena kita takut jika tidak sesuai dengan data yang ada..."

Dengan demikian dapat disimpulkan bahwa baik pimpinan puskesmas maupun pimpinan Dinas Kesehatan telah memiliki kepemimpinan yang kondusif. Hal ini dibuktikan dengan adanya adanya dukungan atas terselenggaranya Sistem Pengendalian Intern Pemerintah (SPIP). Pimpinan menunjukkan tindakan yang responsif, aktif dan reaktif terhadap pelaporan yang berkaitan dengan keuangan, penganggaran, program dan kegiatan, walaupun dalam pelaksanaannya belum tertuang secara resmi dalam Standart Operasional Prosedur (SOP) serta masih dilakukan secara sederhana.

Peraturan Pemerintah Nomor 60 Tahun 2008 Pasal 18 (1) menyatakan bahwa kepala instansi memiliki kewajiban menyelenggarakan aktivitas pengendalian sesuai dengan ukuran, keberagaman urusan, serta sifat dari tugas dan fungsi lembaga 
pemerintah yang bersangkutan. Pada saat melakukan aktivitas pengendalian, kepala puskesmas Tanjung Selor selalu melakukan reviu atas kinerja petugas pengelola kapitasi.

Puskesmas Tanjung Selor juga memiliki kewajiban dalam hal bertanggungjawab terhadap keberhasilan maupun kegagalan pelaksanaan program dan kegiatan dalam menggapai misi dan tujuan lembaga secara terencana, sesuai tujuan atau target kinerja yang disampaikan dalam perencanaan dan penganggaran serta penilaian kinerja yang bersifat secara keseluruhan dan terpadu. Meskipun hasil dari pembagian kapitasi belum mencukupi namun kepala puskesmas tetap mendorong pegawai untuk bertugas secara maksimal. Hal ini sebagaimana yang dituturkan oleh Kepala Puskesmas Tanjung Selor :

"yaa kalau dihitung secara kesejahteraan sih tidak mencukupi, namun ya bagaimana lagi...sebenarnya seperti tanjung selor ini kan dananya besar, SDM juga besar dan kita harus dapat semua,gak mungkin ada yang gak dapat..."

Kegiatan pengendalian terhadap pengelolaan sistem informasi adalah proses yang sangat penting untuk dilaksanakan. Dalam melakukan aktivitas sehari-hari baik dibagian teknis maupun administrasi Dinas Kesehatan telah menggunakan sistem informasi. Namun dalam pengelolaan dana kapitasi ini belum menggunakan sistem informasi apapun, sehingga hanya dilakukan secara manual. Khusus untuk pelaporan keuangan kapitasi sudah menggunakan sistem informasi yaitu Sistem Informasi Manajemen Daerah (SIMDA). Hal ini dikarenakan untuk laporan keuangan kapitasi puskesmas Tanjung Selor masih melekat pada laporan keuangan Dinas Kesehatan karena Dokumen Pelaksanaan Anggaran Kapitasi (DPA) masih bergabung dengan DPA Dinas Kesehatan.

Pengendalian fisik atas aset dilakukan oleh pada sub bagian perlengkapan yang terdiri atas staf penatausahaan barang dan staf petugas akuntansi barang. Pengendalian fisik atas aset yang berasal dari belanja modal dana kapitasi dilakukan dengan pemisahan tugas yang jelas antara petugas penatausahaan barang dengan pengurus barang. Namun yang seringkali terjadi adalah petugas penatausahaan barang tidak melaporkan kepada pengurus barang, sehingga pada saat dilakukan rekonsiliasi barang, seringkali pengurus barang kebingungan karena terjadi selisih antara pencatatan oleh petugas penatausahaan barang dengan barang yang ada. Hal ini bisa menimbulkan potensi adanya kehilangan barang baik aset tetap dan persediaan. Sebagaimana yang diutarakan oleh Kepala Sub Bagian Perencanaan dan Keuangan sebagai berikut :

"Masalah kadang mereka kan belanja barang, harusnya mereka juga melapor ke Muzayyin (petugas barang) biar petugas juga tau ....kadang mereka melapor beli barang ini, tapi petugas barang bingung ini masuk di mana, sekalinya itu barang kapitasi.."

Kegiatan pengendalian juga meliputi kegiatan pendokumentasian secara sistematis terhadap sistem pengendalian intern serta tranksaksi dan peristiwa yang penting. Pendokumentasian terhadap pengendalian intern meliputi dokumentasi yang menggambarkan sistem informasi, penghimpunan dan penanganan informasi serta 
pengendalian yang bersifat umum. Untuk mengatasi kelemahan dan menghindari terjadinya kesalahan yang terletak pada dokumentasi tersebut, pihak puskesmas Tanjung Selor beserta Dinas Kesehatan menyelenggarakan rekonsiliasi mengenai pengelolaan dana kapitasi setiap bulan. Hal ini sesuai dengan yang disampaikan bendahara kapitasi berikut :

"setiap SPJ yang masuk ke saya, saya verifikasi lagi, dicocokkan dengan DPA, apakah pagunya masih ada atau sudah habis...kalau masih ada saya kasih tau pagunya tinggal sekian ya..dan setiap bulan kita selalu mengadakan minlok dengan semua petugas,termasuk pimpus...setelah itu baru disampaikan ke Dinas Kesehatan..."

Dengan adanya kegiatan rekonsiliasi tersebut puskesmas Tanjung Selor berusaha untuk mengatasi kelemahan dalam hal dokumentasi. Atas dasar hasil diskusi di atas, dapat ditarik kesimpulan bahwa proses pengendalian telah dilaksanakan dan pimpinan telah melakukan pemantauan terhadap pencapaian kinerja.

\section{SIMPULAN}

Lingkungan Pengendalian pada pengelolaan dana kapitasi yang terdapat pada Puskesmas Tanjung Selor secara umum telah dilaksanakan dengan baik dan secara tidak langsung telah menjalankan kegiatan pengendalian sebagaimana yang teruang di dalam Peraturan Pemerintah Nomor 60 tahun 2008 tentang Sistem Pengendalian Internal Pemerintah (SPIP). Hanya saja, pelaksanaan kegiatan pengendalian belum memiliki dasar atau belum terdapatnya suatu peraturan resmi yang dibuat secara tertulis yang dijadikan pedoman dalam pelaksanaannya serta ketidaktahuan petugas pengelola kapitasi tentang apa itu sistem pengendalian dan aturan yang telah mengaturnya. Akibat ketidaktahuan tersebut sebagai salah satu sebab belum dibuatnya Standar Operasional Prosedur (SOP) dan petunjuk teknisnya. Pelaksanaan kegiatan pengendalian hanya berdasarkan pada bagaimana melaksanakan kegiatan pengelolaan dana kapitasi tanpa terdapat adanya tindak kecurangan.

Sebagaimana kesimpulan di atas, dapat disampaikan saran, diantaranya dibuatnya Standar Operasional Prosedur (SOP) dan petunjuk teknis pelaksanaan (juknis) sesegera mungkin, yang bisa dijadikan sebagai langkah-langkah pedoman dalam melaksanakan pengelolaan dana kapitasi. Mengingat dana kapitasi rutin diterima setiap bulan oleh puskesmas, dan terdapat kemungkinan setiap bulan semakin bertambah besar. Apabila SOP dan juknis tidak segera diatur, dikhawatirkan tindak kecurangan akan terjadi. Bagi pihak Badan Pengelola Keuangan dan Aset Daerah (BPKAD) untuk bisa membuat suatu sistem informasi yang peruntukannnya khusus dana kapitasi sebagai bagian dari kegiatan pengendalian, sebagai kontrol atas pelaksanaan pengelolaan dana kapitasi oleh pihak eksternal, mengingat dana kapitasi berasal dari masyarakat yang dalam sebagian pengelolaannya dikembalikan kepada msyarakat dan seiring semakin besarnya penerimaan dana kapitasi. 


\section{DAFTAR PUSTAKA}

Basuki. (2016). Metode Penelitian Akuntansi dan Manajemen. Surabaya: Airlangga University Press.

Buku Saku Badan Penyelenggara Jaminan Sosial.

Budiarto, Wasis, dan Lusi Kristiana. (2015). The Use Capitation Funds in the First Level Health Facility (FKTP) Implementasi JKN. Buletin Penelitian Sistem Kesehatan 18(4): 437-445.

Peraturan Menteri Kesehatan Republik Indonesia Nomor 28 Tahun 2014 Tentang Pedoman Pelaksanaan Program Jaminan Kesehatan Nasional.

Peraturan Presiden Nomor 21 Tahun 2016 tentang Pengelolaan dan Pemanfaatan Dana Kapitasi Jaminan Kesehatan Nasional pada Fasilitas Kesehatan Tingkat Pertama Milik Pemerintah Daerah.

Peraturan Presiden Nomor 60 Tahun 2008 tentang Sistem Pengendalian Intern Pemerintah.

Peraturan Presiden No 32 Tahun 2014 Tentang Pengalokasian dan Pemanfaatan Dana Kapitasi Jaminan Kesehatan Tingkat Pertama (FKTP) Milik Pemerintah dan Dukungan Biaya Operasional FKTP Milik Pemerintah Daerah.

Scott, William R. (2013). Financial Accounting Theory. 3rd Ed. New Jersey: Prentice Hall.

Setiaji, T. K., Jati, S. P., dan Arso, S. P. (2015). Analisis Faktor Internal dan Eksternal sebagai Bahan Penyusun Strategi Pencegahan Fraud Dana Kapitasi Puskesmas di Kota Semarang. Jurnal Kesehatan Masyarakat (e-Journal), 3(3), 57-66.

Surat Edaran Menteri Dalam Negeri Nomor 900/2280/SJ. Tanggal 5 Mei 2014 Tentang Petunjuk Teknis Penganggaran, Pelaksanaan dan Penatausahaan, serta Pertanggungjawaban Dana Kapitasi Jaminan Kesehatan Nasional pada Fasilitas Kesehatan Tingkat Pertama Milik Pemerintah Daerah.

Undang-Undang Dasar Negara Republik Indonesia Tahun 1945 pasal 28 H. 